\title{
Comentário AO ARTigo de DOMINIQUE SANTOS, GrAZIELE KOLV E JULIANO JOÃo NAZÁRIO INTITULADO \\ “O ENSino e a PESquisa EM História ANTIGa No \\ BRASIL: REFLEXões A PARTIR DOS DADOS DA \\ Plataforma LatTes"
}

Katia M. P. Pozzer ${ }^{1}$

O resultado da pesquisa realizada por Dominique Santos e sua equipe, ao longo de 2 anos, trouxe à luz uma série de dados empíricos e algumas reflexões importantes sobre o ensino e a pesquisa em História Antiga no Brasil.

A análise foi realizada a partir do grande banco de dados da realidade acadêmica do país que é a Plataforma Lattes, criada em 1999 pelo Governo Federal. O estudo buscava compreender o tamanho da área no Brasil e identificar quais os temas pesquisados.

O artigo inicia por uma contextualização histórica da criação das Universidades no país e o papel desempenhado pela área de Humanidades neste processo, destacando o nome de alguns professores, como o de Eurípedes Simões de Paula, docente da disciplina de História da Civilização Antiga e Medieval, na então recém-criada Universidade de São Paulo.

Dominique Santos, juntamente com a equipe de pesquisa, evidencia, ainda, o surgimento das sociedades científicas, como a ANPUH e a SBEC, criadas com o intuito de articular as ações, divulgar as pesquisas e disseminar os conhecimentos produzidos em História Antiga no Brasil. Vale destacar, também, o trabalho dos primeiros especialistas brasileiros em História Antiga Oriental, os professores Emanuel Bouzon, Ciro Flamarion Cardoso e Emanuel Araújo, que foram responsáveis pelas primeiras publicações de fontes primárias em língua portuguesa no Brasil e pela formação de gerações de novos especialistas.

Partindo de questões sobre o número de professores/pesquisadores na área em efetivo exercício no país, sobre as temáticas que se dedicam a investigar e publicar e sobre o perfil acadêmicos destes profissionais, Dominique Santos coletou dados, organizou-os de forma sistemática e apresentou gráficos com as informações consolidadas.

\footnotetext{
${ }^{1}$ Docente nos cursos de História da Arte e História e do Programa de Pós-Graduação em História (UFRGS).
} 
A análise do número de docentes por região evidencia uma realidade preocupante, a da concentração de especialistas (mais de 50\%) em uma única região (a sudeste). Mas que também é coerente com a situação de grande concentração de instituições de ensino superior.

Outra questão pertinente trazida pelos autores se refere ao nível de internacionalização, tanto da formação, como da interlocução dos pesquisadores, ao analisar o conhecimento de idiomas e países visitados por ocasião de eventos acadêmicos, como congressos, palestras etc. Esses dados revelam uma crescente interlocução/relação com instituições internacionais e são, indiretamente, marcadores da qualidade acadêmica da produção brasileira na área.

Os autores apontam, também, as principais áreas de interesse dos 116 pesquisadores identificados na pesquisa. As civilizações gregas e romanas totalizam $75 \%$ dos objetos de estudo, enquanto as sociedades do mundo oriental, sejam Israel/Palestina, Egito, Mesopotâmia ou Extremo Oriente, não chegam a $7 \%$, somadas, isto é, um número 10 vezes menor do que o de estudos sobre o Ocidente.

O artigo apresenta o número de trabalhos científicos elaborados, como Trabalhos de Conclusão Curso de graduação e especialização, dissertações e teses que acompanham a distribuição dos temas de pesquisa, com nítida supremacia da História Antiga Ocidental.

O estudo, contudo, não apresenta dados ao longo do tempo, como gráficos tendo datas anuais como um dos eixos. Isso possibilitaria a visualização diacrônica dos dados e permitiria uma avaliação por décadas, por exemplo.

Acreditamos que o artigo realiza um exaustivo levantamento de dados acerca da situação da História Antiga no cenário acadêmico brasileiro. Nele ficam evidenciadas a consolidação da área, seu processo de internacionalização e profícua produção intelectual.

Desejamos que estudos dessa natureza possam servir de parâmetros para os órgãos de fomento à pesquisa e ao ensino, no sentido de propor e executar políticas públicas de desenvolvimento científico que contemplem a área de Humanidades com a importância que ela tem e merece. 